\title{
MENINGKATKAN KETERAMPILAN BERPIKIR MAHASISWA DENGAN MENURUNKAN BEBAN KOGNITIF MELALUI INTEGRASI STRUKTUR PADA FUNGSI TUMBUHAN MENGGUNAKAN MODEL NESTED
}

\author{
Anna Fitri Hindriana ${ }^{1,2}$ \\ Adi Rahmat ${ }^{3}$ \\ Sri Redjeki ${ }^{2}$ \\ Riandi $^{3}$ \\ ${ }^{1}$ Mahasiswa Program Studi IPA, Program Pascasarjana UPI \\ ${ }^{2}$ Program Studi Pendidikan Biologi Universitas Kuningan \\ ${ }^{3}$ Jurusan Pendidikan Biologi FPMIPA UPI \\ e-mail : anna_fitri22@yahoo.com
}

\begin{abstract}
Abstrak: Integrasi Struktur pada Fungsi Tumbuhan menggunakan model nested bertujuan untuk meningkatkan keterampilan berpikir mahasiswa. Model ini diperlukan pada saat mahasiswa menerima informasi dengan interkoneksi tinggi, yang dapat menimbulkan beban kognitif. Untuk memfasilitasi keterampilan berpikir terutama penalaran baik induktif maupun deduktif diperlukan adanya model pembelajaran yang dapat menurunkan beban kognitif pada saat mahasiswa menerima informasi. Penelitian ini menggunakan metode pre-eksperimen dengan desain One Group Pre test-Post Test. Subjek dalam penelitian ini terdiri dari 22 mahasiswa yang telah mengikuti mata kuliah Anatomi Tumbuhan. Pengumpulan data dilakukan secara kualitatif dan kuantitatif. Data kualitatif dikumpulkan dari tugas mahasiswa pada saat melakukan analisis informasi dan angket untuk mengetahui beban kognitif mahasiswa pada saat menerima informasi ketika implementasi pembelajaran. Data kuantitatif dikumpulkan dari hasil tes penalaran yang terdiri dari 30 soal pilihan berganda beralasan. Hasil penelitian menunjukan adanya peningkatan yang signifikan pada keterampilan berpikir terutama penalaran induktif setelah diterapkan pembelajaran model nested. Sebagian besar mahasiswa memiliki keterampilan berpikir dan menganalisis informasi dengan kategori baik. Kemampuan penalaran mahasiswa sebesar $68 \%$ termasuk dalam kriteria baik dan 32\% termasuk dalam kriteria cukup. Kemampuan merancang eksperimen mahasiswa sebesar 65\% termasuk dalam kriteria baik. Hanya 35\% mahasiswa yang masih memerlukan bimbingan dalam mengerjakan tugas-tugas yang terkait dengan keterampilan merancang penelitian.
\end{abstract}

Kata Kunci : Integrasi Struktur Pada Fungsi, Penalaran, Model Nested

\begin{abstract}
Integration of teaching subject of plant structure into plant function using nested model aimed to improve student thinking skills when they are receiving information with high interconnection causing cognitive load. To facilitate the thinking skills especially on either inductive or deductive are required a learning model that can decrease cognitive load when the students receiving information caused by the teaching method (extranous load). This research using pre-experimental method with One Group Pre test - Post Test design. Participants of this study were 22 students have took Plant Anatomy Course in previous semester. There are two main data collected in this study, qualitative and quantitative data. Qualitative data were gathered using documents collected from student tasks. Quantitative data were collected using paper and pencil test containing 30 items test measuring students' reasoning skills about plant physiology comprehensively. The result shows that after learning using nested type student thinking skills were increased especially in inductive reasoning. Most students had thinking skill and analysis information skill categorized by good criteria. The reasoning skills of $68 \%$ students had categorized by good criteria and only 32\% of students had reasoning skills belong to sufficient criteria. The experiment design skills of $65 \%$ students were be affiliated with good criteria. We found that no more than $35 \%$ students should be guided during they do the tasts covering experimental design skills.
\end{abstract}

Keyword : Integration Structur To Fuction, Reasoning, Nested Model.

\section{PENDAHULUAN}

Fungsi dan struktur tubuh tumbuhan memiliki hubungan yang sangat erat, keduanya merupakan satu kesatuan yang tidak dapat dipisahkan. Oleh karena itu, untuk mempelajari fungsi jaringan atau organ tertentu, terlebih dahulu harus memahami struktur organ dan jaringan yang dimaksud. Dengan mengintegrasikan struktur tumbuhan pada saat mempelajari fungsi tumbuhan dapat memberikan pengalaman yang ermakna bagi mahasiswa dalam mempelajari fisiologi tumbuhan karena mahasiswa akan selalu menghubungkan struktur terhadap fungsi. Selain itu pengintegrasian struktur pada fungsi tumbuhan dapatmengakomodasi perkembangan tumbuhan, serta memprediksi perubahan fungsi tumbuhan berkaitan 
dengan perubahan struktur tumbuhan akibat perubahan lingkungan. Pengintegrasian struktur tumbuhan pada pembahasan fungsi tumbuhan apabila tidak dikelola dengan baik tentu akan menambah beban kognitif mahasiswa.

Pengintegrasian materi ajar dapat meningkatkan kekuatan untuk menerima, menyimpan, dan menerapkan konsep yang dipelajari. Manfaat keterkaitan konseptual yang dipelajari dengan sisi bidang kajian yang relevan akan membentuk skema kognitif yang memungkinkan mahasiswa memperoleh keutuhan dan kebulatan pengetahuan (Matlin, 2009). Selain itu keterkaitan konseptual dapat menolong mahasiswa untuk memetakan informasi dan mengkatagorisasikan skema yang memungkinkan mahasiswa secara efektif menggunakan pengetahuan yang tepat untuk menghadapi situasi yang berbeda tanpa adanya beban kognitif ekstragenous. Penurunan beban kognitif ekstragenous dapat meningkatkan kapasitas memori kerja yang pada akhirnya akan meningkatkan keterampilan berpikir tingkat tinggi (Mayer,2008).

Penalara melibatkan operasi-operasi mental seperti pembentukan konsep, pembentukan prinsip, pemahaman, pemecahan masalah, pengambilan keputusan dimana hal ini merupakan pengkonstruksian pengetahuan. Penalaran meliputi basic thinking, critical thinking, dan creative thinking. Keterampilan berpikir dasar meliputi kemampuan pemahaman konsep, misalnya melalui pengamatan fenomena, membaca dan diskusi. Sedangkan berpikir kompleks merupakan keterampilan berpikir tingkat tinggi yang meliputi berpikir kritis, berpikir kreatif, pemecahan masalah dan pengambilan keputusan. Agar mahasiswa terbiasa berfikir kompleks maka dalam proses pembelajarannya harus dibiasakan terlibat aktif dalam proses berpikir. Salah satu cara agar mahasiswa aktif dalam proses berpikir adalah dengan cara mengaitkan informasi baru dengan informasi yang sudah tersimpan di dalam ingatannya dan menghubungkannya dan/atau menata ulang dan mengembangkan informasi tersebut untuk mencapai suatu tujuan ataupun menemukan suatu penyelesaian dari suatu keadaan yang sulit dipecahkan (King, Rohani \& Goodson,1997).

Integrasi konsep tipe Nested merupakan tipe yang memadukan berbagai bentuk keterampilan yaitu keterampilan sosial (social skill), keterampilan berpikir (thinking skill) dan keterampilan isi (content-specific skill) ketika membahas suatu topik (Fogarty, 1991). Misalnya ketika siswa mempelajari proses fotosintesis, targetnya adalah memahami konsep "proses". Akan tetapi guru juga mengembangkan keterampilan berpikir siswa dengan cara mengeksplor siswa mengenai faktor-faktor yang menyebabkan dan berpengaruh terhadap proses fotosintesis. Keterampilan sosial juga dikembangkan dengan cara siswa belajar secara berkelompok. Dengan begitu keterampilan- keterampilan tadi "nested" bersama sama sebagai pengalaman belajar siswa.

Integrasi konsep menggunakan tipe nested ini mahasiswa difasilitasi untuk melakukan analitical reasoning, causal reasoning, and purposif reasoning baik secara induktif maupun secara deduktif dengan cara menyediakan sumber belajar, media pembelajaran berupa animasi, bahan diskusi untuk membantu siswa menganalisis informasi konsep struktur dan fungsi tumbuhan yang dilengkapi dengan performance objective. Diskusi dikerjakan dengan cara membuat kelompok kecil secara heterogen, masing-masing kelompok terdiri dari 3-4 orang untuk memecahkan masalah yang berkaitan antara struktur dan fungsi tumbuhan.

\section{METODE PENELITIAN}

Desain yang digunakan dalam penelitian ini adalah One Group Pre test - Post Test. Desain ini memberikan perlakuan pada satu kelompok sampel yang diikuti dengan pengukuran (Creswell, 2008). Sampel terdiri dari 22 mahasiswa semester V tahun ajaran 2011/2012 yang sedang mengikuti mata kuliah Fisiologi Tumbuhan dan telah lulus pada mata kuliah Anatomi Tumbuhan. Konsep yang dipelajari dalam penelitian ini terdiri dari dua topik yaitu transpirasi dan fotosintesis. Untuk mengumpulkan data digunakan tiga jenis instrumen yaitu tugas mahasiswa yang bertujuan untuk membantu menganalisis informasi konsep struktur yang terkait dengan fungsi tumbuhan masingmasing terdiri dari 5 soal. Dalam melakukan analisis informasi konsep struktur yang terkait fungsi tumbuhan mahasiswa ditugaskan untuk melakukan; Identifikasi komponen-komponen struktur yang relevan pada fungsi, integrasi struktur pada fungsi tumbuhan, asimilasi konsep. Soal tes berisi 30 soal pilihan beralasan, yang bertujuan untuk mengukur nalar mahasiswa yaitu analitical reasoning, causal reasoning dan proporsional reasoning.

Hasil tes dianalisis untuk mengetahui kemampuan analisis informasi, peningkatan kemampuan nalar, beban kognitif mahasiswa pada saat menerima informasi (extranous load) setelah implementasi pembelajaran. Pembelajaran di kelas diterapkan menggunakan prinsipprinsip;

1. Memberikan solusi terhadap masalah yang di hadapi mahasiswa dalam belajar

2. Memberikan kesempatan kepada siswa untuk menyelesaikan tugas-tugasnya secara kolaboratif

3. Membuat petunjuk performance objektif yang berisi kata kerja operasional untuk mengarahkan Kinerja mahasiswa dalam mengintegrasikan struktur terhadap fungsi tumbuhan.

4. Menggunakan prior knowledge pada long term memory 
untuk merekonstruksi konsep struktur tumbuhan yang berhubungan dengan konsep yang akan diajarkan.

Integrasi struktur pada fungsi menggunakan model nested terdiri dari tiga tahap yaitu :

\section{Tahap Koneksi Konsep Koheren}

a. Mahasiswa diberi gambaran umum tentang proses fisiologi dan tempat terjadinya di dalam tubuh tumbuhan dibantu dengan media animasi.

b. Mahasiswa diberi permasalahan yang berkaitan dengan perbedaan struktur terhadap fungsi pada tumbuhan.

c. Mahasiswa mengajukan hipotesis serta alas an penarikan hipotesis berdasarkan perbedaan srtuktur melalui pengintegrasian konsep yang koheren.

\section{Tahap Pembentukan Konsep.}

a. Mahasiswa diminta merancang eksperimen yang berkaitan dengan perbedaan struktur terhadap fungsi yang dilakukan oleh tumbuhan.

b. Mahasiswa merumuskan prinsip-prinsip proses fisiologi pada tumbuhan berdasarkan perbedaan struktur organ yang berperan dalam proses fisiologi tersebut.

c. Mahasiswa diminta untuk mengintegrasikan sendiri konsep-konsep jaringan pada organ tumbuhan yang berhubungan dengan proses fisiologi dengan cara membuat skema kognitif berupa peta pikiran (mind map).

\section{Tahap Pembentukan Konsep.}

a. Mahasiswa menuliskan skema berbasis koherensi dan integrasi konsep perbedaan struktur pada fungsi tumbuhaan terhadap strategi adaptasi terhadap lingkungannya yang dilakukan oleh tumbuhan.

b. Dosen merekonstruksi konsep-konsep perbedaan struktur tumbuhan yang berhubungan dengan strategi adaptasi yang dilakukan pada proses fisiologi.

Pengumpulan data dilakukan secara kualitatif dan kuantitatif. Data kualitatif dikumpulkan dari: (1) dokumen jawaban mahasiswa dalam menganalisis informasi yang dilengkapi dengan performance objective, yang bertujuan untuk menganalisis struktur tumbuhan yang terkait fungsi, menganalisis strategi adaptasi yang dilakukan oleh tumbuhan dengan mengaitkan struktur tumbuhan pada fungsi tumbuhan, melakukan interpretasi data yang mengaitkan antara struktur tumbuhan pada fungsi tumbuhan dan merancang eksperimen yang dibatasi waktu. (2) jawaban angket mahasiswa untuk mengetahui beban kognitif mahasiswa pada saat menerima informasi yang diakibatkan oleh model mengajar (extranous load) setelah implementasi pembelajaran. Data kuantitatif dikumpulkan dari hasil tes penalaran. Seluruh data dianalisis secara deskriptif menggunakan prosentase pencapaian.

\section{HASIL DAN PEMBAHASAN}

\section{Kemampuan Analisis informasi.}

Kemampuan analisis informasi konsep transpirasi umumnya termasuk dalam kriteria baik, dengan rincian $65 \%$ termasuk kriteria baik dan $17 \%$ termasuk kriteria baik sekali, sedangkan 18\% kriteria cukup. Dalam melakukan analisis informasimahasiswa sudah mampu a) mengidentifikasi komponen-komponen struktur yang relevan pada fungsi, mahasiswa dapat memahami jaringanjaringan pada organ akar, batang dan daun yang berperan dalam proses transpirasi. b) mengidentifikasi persamaan dan perbedaan jaringan pada suatu organ, misalnya mahasiswa sudah mampu membedakan jaringan pada tumbuhan dikotil dan monokotil yang berpengaruh terhadap kecepatan transpirasi. c) Mengkontruksi dukungan dengan mengajukan bukti perbedaan struktur tumbuhan terhadap strategi adaptasi yang dilakukannya. Mahasiswa mampu dengan baik membedakan struktur yang berpengaruh terhadap transpirasi dengan cara menganalisis jaringan daun pada tumbuhan yang hidup di daerah hidrofit, mesofit dan xerofit. Analisis jaringan terutama dilihat pada struktur mesofil, epidermis, bentuk stomata dan letak stomata. $62 \%$ mahasiswa sudah mampu merancang eksperimenberkaitan dengan organ yang dimiliki oleh tumbuhan terhadap laju transpirasi. Mahasiswa sudah mampu memilih jenis tumbuhan. Pada saat merancang eksperimen transpirasi, mereka memilih tumbuhan yang batangnya tidak berkayu dan memiliki daun yang lebar serta tipis. Mereka telah mampu membuat cara kerja secara jelas, dan telah mampu menarik hipotesis serta alasan penarikan hipotesis tersebut berdasarkan struktur tumbuhan. 38\% mahasiswa masih sulit merancang eksperimen karena mereka cenderung menggunakan jenis tumbuhan yang berbeda dan membandingkan perbedaan jaringan organ tumbuhan tersebut berdasarkan prinsip transpirasi. Penarikan hipotesis sudah benar, begitupun dengan alasan penarikan hipotesis namun mereka tidak memahami prinsip apa yang diminta pada saat merancang eksperimen.

Kemampuan analisis informasi konsep fotosintesis lebih baik dari konsep transpirasi, hal ini disebabkan konsep transpirasi memiliki interkoneksi yang tinggi antara struktur terhadap fungsi. kompleksitas informasi melebihi kapasitas memori kerja dapat mengakibatkan dampak negatif pada pemahaman materi. Interkoneksi yang tinggi pada konsep transpirasi dapat dilihat ada tiga organ utama yang berpengaruh terhadap laju transpirasi dan strategi adaptasi yang dilakukan oleh tumbuhan saat melakukan transpirasi, sedangkan pada konsep fotosintesis hanya satu 
organ utama yang berpengaruh terhadap laju fotosintesis dan strategi adaptasi yang dilakukan oleh tumbuhan saat melakukan fotosintesis.

Kemampuan analisis informasi konsep fotosintesis umumnya termasuk dalam kriteria baik, 83\% termasuk kriteria baik dan $17 \%$ termasuk kriteria baik sekali. Dalam melakukan analisis informasi mahasiswa sudah mampu a) mengidentifikasi komponen-komponen struktur yang relevan pada fungsi, mahasiswa dapat memahami jaringanjaringan pada organ daun yang berperan dalam proses fotosintesis. b) mengidentifikasi persamaan dan perbedaan jaringan pada suatu organ. Mahasiswa sudah mampu membedakan jaringan pada daun dikotil dan monokotil yang berpengaruh terhadap kecepatan fotosintesis. c) Mengkontruksi dukungan dengan mengajukan bukti perbedaan struktur tumbuhan terhadap strategi adaptasi yang dilakukannya. Mahasiswa mampu dengan baik membedakan struktur yang berpengaruh terhadap fotosintesis dengan cara menganalisis jaringan daun pada tumbuhan $\mathrm{C} 3, \mathrm{C} 4$, dan $\mathrm{CAM}$ terutama dilihat dari struktur mesofil, epidermis, bentuk stomata dan letak stomata. Mahasiswa telah mampu melakukan asimilasi konsep dengan cara menerapkan konsep fungsi jaringan suatu organ terhadap efektivitas fotosintesis, contoh; mahasiswa mampu menerapkan prinsip fungsi adanya seludang pembuluh pada tumbuhan jagung, sehingga tumbuhan tersebut dalam kondisi suhu yang panas dan intensitas matahari yang tinggi dapat mencegah terjadinya fotorespirasi meskipun kadar $\mathrm{CO} 2$ di udara rendah. Pada saat dosen memberikan permasalahan adanya peningkatan suhu, mahasiswa secara spontan akan mengaitkan peranan enzim dalam proses fisiologi pada tumbuhan serta menghubungkannya dengan struktur yang dimiliki oleh jaringan tumbuhan C4 dan CAM. 68\% mahasiswa telah memiliki kemampuan merancang eksperimen. Dalam merancang eksperimen mereka telah mampu memilih jenis tumbuhan yang akan digunakan. Mahasiswa mampu memberikan alasan pemilihan tumbuhan tersebut berdasarkan strukturnya sehingga tujuan dari eksperimen terpenuhi. Mereka telah mampu membuat cara kerja secara jelas, dan telah mampu menarik hipotesis serta alasan penarikan hipotesis tersebut berdasarkan struktur tumbuhan. $32 \%$ yang belum mampu merancang eksperimen, mereka masih memerlukan bimbingan terutama dalam memberikan alasan penggunaan jenis tumbuhan tertentu serta menarik hipotesis.

Kemampuan mahasiswa mengintegrasikan pengetahuan tentang struktur tum tumbuhan pada fungsi tumbuhan pada situasi tertentu umumnya sudah baik, mereka dapat menyebutkan jenis tumbuhan serta karakteristik jaringan tumbuhan tersebut berdasarkan ciri khusus dalam melakukan strategi adaptasi terhadap lingkungannya, mereka telah mampu menerapkan konsep jenis tumbuhan terhadap kemampuan melakukan fotosintesis berdasarkan keterkaitan struktur terhadap fungsi.

\section{Kemampuan Penalaran}

Kemampuan penalaran mahasiswa setelah diterapkannya model Nested menunjukan peningkatan. Rata -rata nilai pre test adalah 32,9 dengan simpangan baku 7,29 sedangkan rata-rata nilai post test adalah 63,18 dengan simpangan baku 6,97. Berdasarkan hasil rata-rata posttest dan hasil rata-rata pretest didapat nilai rata-rata gain sebesar 0,45 dengan demikian peningkatan kemampuan penalaran setelah diterapkannya model nested termasuk dalam kategori sedang. Kemampuan penalaran tersebut menunjukkan bahwa $57,7 \%$ termasuk kedalam criteria baik, dan 23\% termasuk kriteria cukup. Kemampuan penalaran induktif lebih baikdibandingkan penalaran deduktif. Kemampuan penalaran induktif mahasiswa 38\% termasuk dalam kriteria baik sekali, 38\% termasuk dalam kriteria baik, sedangkan $24 \%$ termasuk dalam kriteria cukup sedangkan kemampuan penalaran deduktif mahasiswa $20 \%$ termasuk dalam kriteria baik sekali, $40 \%$ termasuk dalam kriteria baik dan $40 \%$ termasuk dalam kriteria cukup.

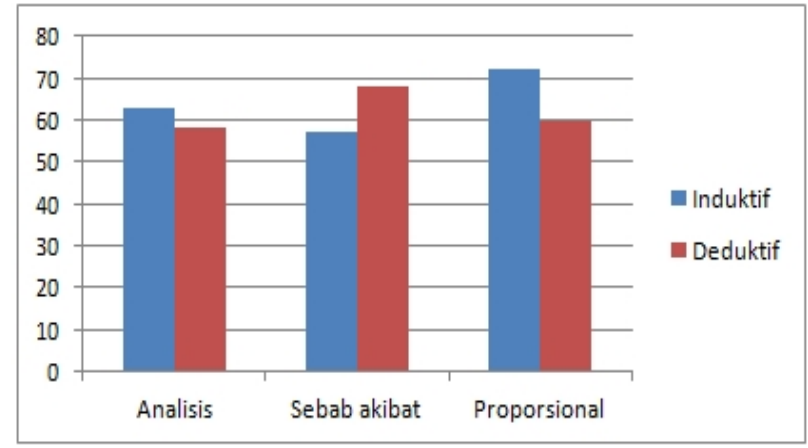

Gambar 1. Perbandingan Kemampuan Penalaran Induktif dan Deduktif

Kemampuan penalaran proposional induktif mahasiswa lebih tinggi dibandingkan penalaran analisis dan penalaran sebab akibat, hal ini disebabkan mahasiswa mampu membandingkan struktur jaringan tumbuhan secara kuantitatif dengan proses fisiologi, sebagai contoh pada konsep transpirasi mahasiswa membandingkan jumlah dan sebaran stomata terhadap kecepatan transpirasi, jumlah dan panjang akar terhadap kemampuan menyerap tumbuhan, sehingga mahasiswa mampu menerapkan prinsip struktur yang berkaitan dengan fungsi serta menerapkannya pada proses transpirasi. begitupun pada kemampuan penalaran analisis secara induktif termasuk dalam kriteria baik, hal ini disebabkan mahasiswa sudah mampu melihat hubungan sebab akibat antara perbedaan struktur suatu organ tumbuhan terhadap fungsi tumbuhan, 
mereka mampu memberikan alasan yang tepat terkait perbedaan struktur terhadap proses fisiologi, sebagai contoh keterkaitan bentuk stomata terhadap kecepatan transpirasi dan efektivitas fotosintesis, mereka dapat memberikan alasan bahwa stomata bentuk halter yang terdapat pada tumbuhan monokotil dapat mencegah laju transpirasi yang tinggi karena stomata tersebut membuka tetapi tidak terlalu lebar dan sekaligus cukup untuk masuknya $\mathrm{CO} 2$ yang diperlukan untuk proses fotosintesis.

Kemampuan penalaran deduktif sebab akibat lebih tinggi dibandingkan penalaran deduktif analisis dan penalaran deduktif proporsional hal ini disebabkan karena mahasiswa telah mampu melihat hubungan sebab akibat dalam menerapkan prinsip struktur tumbuhan pada fungsi tumbuhan, merek mampu berpikir beberapa tahap sebelum memberikan alasan. Sebagai contoh mereka dapat mengetahui penyebab mengapa tumbuhan dapat melakukan siklus hidup dengan sempurna di daerah xerofit dengan melihat strategi adaptasi yang dilakukan oleh tumbuhan dalam memanfaatkan cahaya matahari secara maksimal.

\section{Beban Kognitif Mahasiswa pada Saat Menerima Informasi.}

Beban kognitif mahasiswa pada saat menerima informasi yang diakibatkan oleh model nested pada saat implementasi pembelajaran rata-rata 2,8 dari skala 5 . Angka 2,8 ini menunjukkan penggunaan model nested untuk mengintegrasikan struktur tumbuhan pada fungsi tumbuhan tidak terlalu membebani mahasiswa, meskipun integrasi struktur tumbuhan pada fungsi tumbuhan pada konsep transpirasi dan fotosintesis memiliki interkoneksi yang tinggi.

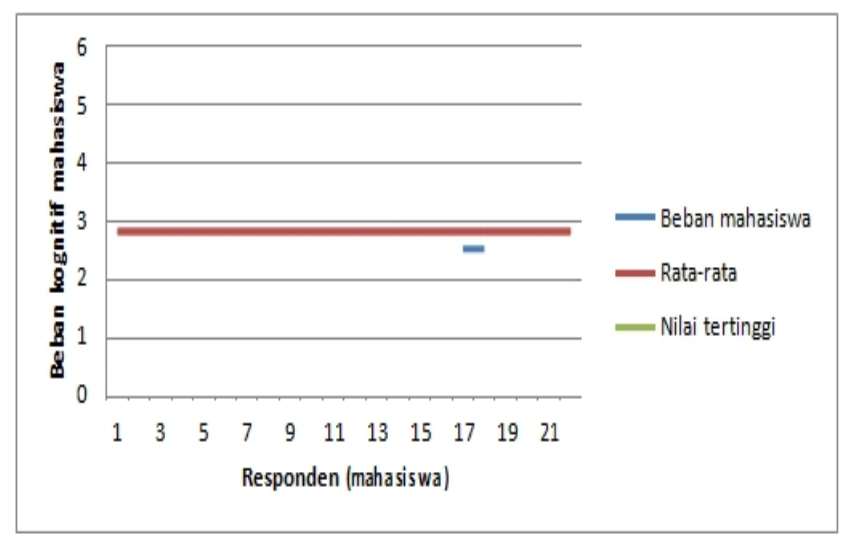

\section{Gambar 2. Beban kognitif mahasiswa pada saat implementasi model}

Usaha mahasiswa dalam memahami keterkaitan antara struktur tumbuhan dan fungsi tumbuhan rata- rata berada dalam kategori mudah dengan skor 2, contoh pada saat mereka merumuskan prinsip-prinsip strategi adaptasi tumbuhan dengan melakukan analisis struktur tumbuhan, namun pada saat mereka harus mengintepretasikan pengaruh lingkungan terhadap proses fisiologi berdasarkan strukturnya melalui pengintegrasian konsep yang koheren, rata-rata dalam kategori tidak mudah tapi tidak sulit dengan skor 3. Sebagian besar mahasiswa memilih kategori sulit dengan skor 4 pada saat mereka diminta untuk merancangek eksperimen, hal ini disebabkan pada saat merancang eksperimen mahasiswa diharuskan membuat cara kerja, mengajukan hipotesis dan alasan pengajuan hipotesis. Walaupun kemampuan merancang eksperimen sudah mencapai $62 \%$ untuk konsep transpirasi dan $68 \%$ untuk konsep fotosintesis, namun berdasarkan angket sebagian mahasiswa merasa sulit untuk dapat membuat rancangan eksperimen.

\section{Implikasi penurunan beban kognitif mahasiswa terhadap kemampuan penalaran dan kemampuan analisis informasi.}

Integrasi struktur tumbuhan pada fungsi tumbuhan menggunakan model nested memberikan pengaruh yang positif terhadap proses berpikir mahasiswa. Pengaruh positif tersebut terutama dalam usaha mereka untuk memahami konsep kompleks pada mata kuliah Fisiologi tumbuhan. Fisiologi Tumbuhan dibangun oleh beberapa konsep struktur tumbuhan yang telah dipelajari oleh mahasiswa pada mata kuliah Anatomi Tumbuhan. Mahasiswa membutuhkan pembiasaan dalam menggunakan prior knowledge dalam berpikir pada situasi baru dimana mahasiswa harus mengkoneksikan antar konsep. Integrasi struktur tumbuhan pada fungsi tumbuhan merupakan salah satu usaha untuk mengintegrasikan perkembangan dan pertumbuhan mahasiswa serta kemampuan pengetahuannya. Pembelajaran terpadu model nested adalah pendekatan untuk mengembangkan kemampuan nalar dalam pembentukan pengetahuan berdasarkan interaksi dengan lingkungan dan pengalaman dalam kehidupannya.

Sehubungan dengan itu, pendekatan pembelajaran terpadu model nested membantu mahasiswa untuk belajar menghub menghubungkan apa yang telah dipelajarinya dengan yang baru mereka pelajari. Integrasi struktur tumbuhan ketika mempelajari mata kuliah Fisiologi Tumbuhan memfasilitasi mahasiswa membentuk skema kognitif, pembentukan skema kognitif memungkinkan mahasiswa memperoleh pengetahuan yang bersifat holistik melalui keterkaitan konseptual materi yang sedang dipelajari dengan bidang kajian yang relevan. Selain itu pengintegrasian struktur tumbuhan pada fungsi tumbuhan memfasilitasi penggunaan berbagai proses kognitif yang menekankan pada keterampilan berpikir, dan mengatasi kesulitan tugas kognitif yang dihadapi mahasiswa. Kesulitan tersebut disebabkan oleh kapasitas kognitif yang 
berbeda antar mahasiswa.

Keterampilan berpikir dapat dikembangkan dan diperkaya melalui pembelajaran yang bermakna. Pembelajaran yang memberi kesempatan kepada calon guru untuk memperoleh keterampilan-keterampilan dalam pemecahan masalah dapat merangsang keterampilan bernalar mahasiswa. Pengalaman ini diperlukan agar calon guru memiliki struktur konsep yang berguna untuk menganalisis dan mengevaluasi suatu permasalahan. Pada model nested melalui topik transpirasi dan fotosintesis peneliti telah mencoba mengembangkan keterampilan berpikir calon guru.

Calon guru yang memiliki keterampilan berpikir yang baik diharapkan mampu membelajarkan siswanya bernalar. Dengan bernalar siswa mampu berpikir dan bertindak secara normatif, siap bernalar tentang sesuatu yang mereka lihat, dengar, atau pikirkan.

\section{SIMPULAN}

Integrasi struktur pada fungsi tumbuhan menggunakan nested model dapat;

1. Meningkatkan keterampilan berpikir dalam hal menganalisis informasi dan bernalar saat mahasiswa mempelajari fisiologi tumbuhan.

2. Memfasilitasi mahasiswa membentuk skema kognitif yang memungkinkan memperoleh pengetahuan yang bersifat holistik melalui keterkaitan konseptual materi yang sedang dipelajari dengan bidang kajian yang relevan.

3. Memfasilitasi penggunaan berbagai proses kognitif yang menekankan pada keterampilan berpikir, dan mengatasi kesulitan tugas kognitif yang dihadapi mahasiswa yang disebabkan oleh kapasitas kognitif yang berbeda antar mahasiswa.

\section{DAFTAR PUSTAKA}

Borg,W.R. \& Gall,M.D., (2003). Educational Research: An Introduction. New York: Longman

Brookhart,S.M., (2010), Assess Higher Order Thinking Skill in Your Classroom, Virginia USA: ASCD. Creswell,J.W., (2008), Educational Research, Singapore, Canada, Japan, Australia, North Asia, Malaysia, Mexico, New Jersey: Pearson Education,Ltd.

Dahar,R.W.,(1989), Teori-teori Belajar,Jakarta: Erlangga. DeLeew.K.L.,Mayer.R.G., (2008), “A Comparison of Three Measures of Cognitive Load: Evidence for Separable Measures of Intrinsic Extraneous, and Germane Load". Journal o Education Psychology.100, (1), 1223-1234.

Fogarty,R., (1991), How To Integrate The Curricula Illionis, Skylight Publishing.Inc. 